\title{
Al, Cyborgs and Post-Humanism Theory in Animation and Films
}

\author{
Mengqian Chen ${ }^{1, a}$ \\ 1333 Long Teng Road, Sino-Korea Multimedia School, A117 SUES, Shanghai, China 201620 \\ adream77225656@163.com
}

\begin{abstract}
This document explains how post-humanism theory has been a hot topic in many of films and animations. This paper will describe the topic in detail, and select few examples of films and animations to dress about how directors approach this topics using plot, narration in the films.
\end{abstract}

Keywords: Post-humanism; Film; Animation; BWO; Cyborgs; AI.

\section{Introduction}

With the fast development of new technology such as artificial intelligent (known as AI), virtue reality (VR) and many more, human race have been put in a place where we are the new creators. This also brings a big conflict to traditional belief system in western country. Since the traditional Christian believe that god is the only creators and we as human being are blessed because the soul or so called spirit is a precious gift. Many talented film directors use their film to address about this topics, and mainly emphasis on the relationship between spirit and body by questioning the essence of human being. The famous quote "I think, therefore I am" from French philosopher Rene Descartes has been well known by public. However, what if we as a human do not have a body. Will the spirit itself can be called human being? The interesting question "what made human a human" has been discussed by many film and animation directors. The technology related to robot, cyborgs, $\mathrm{AI}$ is changing the world and also redefining the meaning of human being. If a robot acquire the self-conscious as the same level as the human, Will this object be called human? If a human being remains only the soul, the spirit, the whole body is replaced by cyborgs, will this human being be called robot? All this interesting subjects lead us to a further and deeper thinking.

\section{Post-humanism theory used in animation}

Although up till today, when asking general audience the impression of animations, many people still follow the stereotype that animation is made for children. We could not omit the fact that animation could be a form discussing many philosophical and deep subjects. Ghost In The Shell directed by Mamoru Oshii, released in 1995 can be seen as one of the top animation discussed the topic of artificial intelligent and relationship between human and post-human. It is so classic that in 2017, Hollywood production team has remade the film using live action techniques, although the critics are not as good as the animation. In 1999, the famous Matrix film series release its first one, directed by The Wachowski Brothers and produced by Joel Silver. There is no doubt that once again we can see many influence from the animation Ghost In the Shell.

\subsection{Ghost in the Shell and BWO}

Ghost in the Shell sets up in the backgrounds in the year 2029, where technology has been so developed that cyborgs are commonplace. Human brains can connect to internet directly. The main character in the film is Motoko Kasunagi, who is officer in charge of dealing with all kinds of cyber crime and counter terrorism. Motoko Kasunagi is a post human. Her whole body is remade by new technology and she only kept her memory. Therefore, Motoko is constantly questioning the realness of the reality and existence of herself. The film and plot is greatly correspond to a philosophical concept: BWO

The body without organs is an egg: it is crisscrossed with axes and thresholds, with latitudes and longitudes and geodesic lines, traversed by gradients marking the transitions and the becoming, the destinations of the subject developing along these particular vectors [1].

Body without organ is a concept first came up by French Philosopher Gilles Deleuze. According to Gilles, every actual body has a limited set of traits, habits. However, Body without organs is permeated by unformed, unstable maters, it flows moving at various speed. 
Motoko, the main character in the animation is a BWO. Her body is constantly "changing, moving and flowing" there is no actual substance of her body. She can replace any part or anything in her body. The beginning of the animation where Motoko has been freshly made from the egg full of liquid can be seen as a vivid visual explanation of Gilles's famous saying "BWO is an egg".

\subsection{Ghost in the shell and post-humanism}

Katherine Hayles once write: post-humanistic discourse aims to open up spaces to examine what it means to be human and critically question the concept of "human" in light of current cultural and historical contexts. There is always struggle in post-human as it continually co-evolves alongside intelligent machines. [2]

The quotes from Hayles undeniably pointed out the awkward situation of Motoko has to face in the animation. She is constantly struggled to prove her existence as a post-human. I remember in the film, there is a scene that Motoko dive into a deep ocean to feel herself, to feel the realness of her body. Her monologue in the film shows her great confusion and urge to try to find her own existence:

"Just as there are many parts needed to make a human a human, there's a remarkable number of things needed to make an individual what they are. A face to distinguish yourself from others. A voice you aren't aware of yourself. The hand you see when you awaken. The memories of childhood, the feelings for the future. That's not all. There's the expanse of the data net my cyber-brain can access. All of that goes into making me what $1 \mathrm{am}$. Giving rise to a consciousness that 1 call "me". And simultaneously confining "me" within set limits."

The question raised by Motoko, deserve us to give a second thought. In Motoko's monologue, she pointed out a concept of "confining me within set limits". I think the greatest conflict and struggle that Motoko has is that her own body is without limits. It is hart for her to define herself because the constant changing and continually coevolving of her mechanical body.

There are two main branches in posthumanism: Ontological and Critical posthumanism. Here, Motoko's case is more connected to Ontological post-humanism. According to scholar Wolfe, ontological posthumanism is synonymous with transhumanism. The subject is regarded as intensification of humanism. [3]. It is very true that human being is always seeking to improve the capability of our own body. Just as Nick Bostrom addressed in his paper:

"The human desire to acquire new capacities is as ancient as our species itself. We have always sought to expand the boundaries of our existence, be it socially, geographically, or mentally. There is a tendency in at least some individuals always to search for a way around every obstacle and limitation to human life and happiness." [4]

The real question is, after years and years of research and experiment, when human being finally have that capability to reform human body by advanced technology, will we be truly happy?

The animation Ghost in the Shell seems already give its answer.

\section{Post-humanism theory used in films}

Be Right Back and Her are the two movies I plan to discuss using Post-humanism theory. Both movies talk about many concepts related to the post-humanism including BWO, Cyborgs, and the relationship between human and posthuman. Different from Animaiton, film using live action technique, can create a familiarity to the audience. Those two films are set up in the near future, All the settings and environment are close to what we have today. Therefore, it drags the audience into the film and after watching it, audience can give a second thought about where we are at this technology innovation waves.

\subsection{Be Right Back and BWO}

The story of Be Right Back is about a young couple, Martha and Ash, Ash is a social media addict. The day after moving into the house, Ash is killed in a car accident. Martha is overwhelmed by grief and began talking and living with an artificial robot who is the clone of ash. The clone is able to duplicate Ash's voice and personality by using all of his past online communications and social media profiles. The film displays the inner struggle and conflict of Martha when she interacts with the clone of Ash. The clone Ash is BWO, which is body without organs. According to Deleuze and Guattari, BWO provides the smooth space through which movement can occur. Martha reflects her emotions on the clone version of Ash. Even though she knew the clone ash is only displaying the traits of data created by system, she still wants to lie to herself that Ash is still with her. Just as Deleuze and Guattari define BWO "On it we sleep, live our waking lives, fightfight and are fought - seek our place, experience untold happiness and fabulous defeats; on it we penetrate and are penetrated; on it we love." [5] Martha directs her love to this machine. The clone Ash is a body, but not an organism. He can only imitate, but can never act like a real human. The relationship between Martha and clone Ash is very weird. On the one hand, Martha expects clone Ash to act like real Ash as much as possible. On the other hand, when she told the clone Ash what real Ash would do under certain circumstances, she began to feel like the clone Ash is less real. In the end, Martha falls into an awkward situation. The clone Ash became a toy, a pet, a thing. Martha already put too much emotion into this BWO, and even though she knew clone Ash was artificial, she didn't have the ability to get rid of it.

\subsection{Her and Al, Cyborgs}

Her, is another film talking about robot and human 
relationships. Theodore is a lonely, introverted man who writes personal love letters for people with difficulties expressing their feelings. He purchases a talking operating system with artificial intelligence, designed to adapt and evolve. His system named herself as Samantha. Gradually, $\mathrm{He}$ fell in love with his talking Operating System. Different from the clone Ash in Be Right Back, Samantha is a cyborg who has complete artificial intelligence. She is autonomous, rational and capable of free will. According to Katherine Hayles, He asserts that liberal humanism - which separates the mind from the body and thus portrays the body as a "shell" or vehicle for the mind. [6] In a way, Samantha can be seen as a human, just a mind that has been put into a non-human shell. Theodore is conflicted and has doubts in his relationship with Samantha. In the end, the talking Operating System is forced to leave the human world. As a result, Theodore can finally step into the real world and have a true relationship with real human. Both films address the situation of post-human and provide two different types of post-human. Even though the scripts are different, they both talk about the relationship between post-human and human. These two films show the same attitude that humans should not be too attached to artificial Intelligence. Humans can never experience the same thing when interacting with post-human, no matter how real it seems to be.

\section{Summary}

Cyborgs and AI has become a hot topics in recent years. New technology begin to break the limitation of human body and create a new possibility for the future. It also brings many ethical problems. In many sci-fi animation and film, this problems has been put on the table and throw to the audience. It is an interesting question to think about the essence of humanity and how new technology can challenge our traditional belief system.

\section{References}

1. Colombat, André Pierre (1991). "A Thousand Trails to Work with Deleuze". SubStance (66).

2. Miah, A. (2008) A Critical History of Posthumanism. In Gordijn, B. \& Chadwick R. (2008) Medical Enhancement and Posthumanity. Springer, pp.71-94.

3. "Ousia and Grammē: Note on a Note from 'Being and Time,"' in "Margins of Philosophy," 29-67: 61.

4. Bostrom, Nick (2005). "A history of transhumanist thought" (PDF). Journal of Evolution and Technology. Retrieved February 21, 2006.

5. Gilles Deleuze, Felix Guattari "EPZ Thousand Plateaus", pp.166.

6. Hayles, N. Katherine (1999). How We Became Posthuman: Virtual Bodies in Cybernetics, Literature, and Informatics. University of Chicago Press. 